Jurnal Syntax Imperatif: Jurnal Ilmu Sosial dan Pendidikan

p-ISSN: 2721-2491 e-ISSN :2721-2246

Vol. 1, No. 4, September 2020

\title{
Analisis Pesan Dakwah Melalui Channel Youtube Ustadz Ucu Najmudin
}

\section{Syarah Siti Maesyaroh, Andri Hendrawan}

Program Studi Komunikasi dan Penyiaran Islam, Sekolah Tinggi Agama Islam (STAI) Persis Bandung, Indonesia

Email: ssyarah077@gmail.com, sas.hendrawan84@gmail.com

\begin{abstract}
Abstrak
Perkembangan teknologi informasi mengalami kemajauan sangat pesat. Kemajuan tersebut telah mengantarkan umat manusia semakin mudah untuk berhubungan satu dengan lainnya. Salah satu yang saat ini sedang merebak kepada publik adalah hadirnya sebuah media baru, yakni Youtube. Media Youtube ini menjadi salah satu topic hangat dikalangan banyak umat, termasuk umat Islam. umat islam bisa memanfaatkan media Youtube ini sebagai media untuk menyebarkan kebaikan, agar islam dan elemennya mampu terpublikasi secara masal melalui media informasi ini. Penelitian ini bertujuan untuk mengetahui bagaimana peran Ustadz Ucu Najmudin sebagai tokoh agama memanfaatkan serta menyebarkan materi dan pesan dakwah kepada para mad'u melalui media Youtube, dan bagaimana strategi beliau menyampaikan pesan dakwah tersebut. Dalam penelitian ini, penulis menggunakan metode analisis konten. Pengumpulan data menggunakan teknik analisis serta dokumentasi secara langsung melalui tayangan video yang ada di channel Youtube ustadz Ucu Najmudin. Data yang dikumpulkan dianalisis, dideskripsikan dan ditafsirkan dengan menggunakan teori-teori yang ada sebagai acuan dalam analisa data. Permasalahan yang terdapat dari penelitian ini, sulitnya mendapat profil elngkap ustadz Ucu Najmudin, kebanyakn video kualitas rendah, serta video yang diupload kebanyakan bukan dari official Youtube Channel Ustadz Ucu Najmudin. Hasil penelitian ini video pesan dakwah melalui media Youtube yang dilakukan oleh ustadz Ucu Najmudin sangat baik. Meskipun komunikasi yang terjadi hanya satu arah, pesan dakwah yang diberikan oleh ustadz Ucu Najmudin mampu dipahami oleh para mad'u, dengan penyampaian menggunakan bahasa sehari-hari serta diselingi guyonan-guyonan, membuat mad'u dengan mudah mengerti dan faham.
\end{abstract}

Kata kunci: Komunikasi; Pesan dakwah; Media;

\section{Pendahuluan}

Di zaman modern ini dakwah bukan hanya dilakukan dengan mengadakan pengajian langsung. Sekarang sudah banyak cara bisa dilakukan untuk berdakwah, misalnya, melalui media TV, radio, dan lain lain. Dakwah sendiri adalah (Arab: , دعوة da'wah; "ajakan") kegiatan yang bersifat menyeru, mengajak dan memanggil orang untuk beriman dan taat kepada Allah sesuai dengan garis aqidah, syari'at dan akhlak Islam. Kata dakwah merupakan masdar (kata benda) dari kata kerja da'a yad'u yang berarti panggilan, seruan atau ajakan.

Menurut Muhammad Nasir dakwah adalah usaha menyerukan dan menyampaikan kepada perorangan manusia dan seluruh umat tentang pandangan dan tujuan hidup manusia di dunia yang meliputi amar ma'ruf nahi munkar, dengan berbagai macam media dan cara yang diperbolehkan oleh akhlak, dan membimbing pengalamannya dalam perikehidupan perseorangan, berumah-tangga, bermasyarakat, dan bernegara 
Pada dasarnya, komunikasi dakwah dapat menggunakan berbagai media yang dapat merangsang indra-indra manusia serta dapat menimbulkan perhatian untuk penerimaan dakwah. Komunikasi dakwah sebenarnya semakin tepat dan efektif media yang dipakai semakin efektif pula upaya pemahaman ajaran islam pada komunikasi dakwah. Berdasarkan banyaknya, komunikator yang dijadikan sasaran diklarifikasikan menjadi dua, yaitu "media massa" dan "media nirmasa". (Ilaihi \& Kamsyah, 2010, p. 105)

Dalam menjalani prosesnya, dakwah sebagai kegiatan meneru kepada kebaikan dapat dilakukan dengan berbagai macam cara, diantaranya dapat dilakukan dengan cara khutbah dan khitabah. Khutbah adalah bidang yang mengkaji tentang teknik berpidato sebagai bagian proses dakwah bil al-islam. Sedangkan khitabah, merupakan bidang yang mengkaji menulis sebagai kegiatan dakwah bil-kalam. (Indrawati, 2013)

Dakwah dapat dikatakan sebagai bentuk komunikasi yang khas dengan islam karena suatu misi yang berbeda dengan komunikasi pada umumnya, bila komunikasi pada umumnya adalah untuk melakukan perubahan sesuai dengan kehendak komunikatornya, sedangkan dakwah tidak hanya berhenti pada komunikator, tapi jauh lebih mengempan pada sebuah misi yang berhubungan dengan dunia akherat. Karenya dalam dakwah terdapat misi yang berkesinambungan yang telah diprakarsai oleh para Rosul khususnya Nabi Muhammad Saw. sebagai Nabi yang mengemban tugas menjadi da'i (juru dakwah) bagi seluruh manusia.(Kustandi Suhendang, 2007, p. 13)

Komunikasi bermedia (media communication) disebut juga dengan komunikasi tak langsung, dan ebagai konsekuensinyapun arus balik pun tidak terjadi pada saat komunikasi dilancarkan. Untuk itu, komunikasi melalui media disebut komunikasi satu arah sehingga komunikator tidak mengetahui tanggapan komunikan dengan seketika. Komunikator tidak mengetahui tanggapan komunikan pada saat ia berkomunikasi.

Oleh karena itu untuk melancarkan komunikasi bermedia, komunikator harus lebih matang dalam merencanakan dan mempersiapkan sehingga ia merasa pasti bahwa komuikasinya tersebut akan berhasil. Komunikasi yang dituju dengan menggunakan media, bentuknya bisa hanya seorang, dapat dengan kelompok kecil orang, bisa juga sejumlah orang yang amat banyak. (Ilaihi \& Kamsyah, 2010, p. 105)

Dalam perkembangan islam saat ini, bagaimana islam dan elemennya mampu terpublikasi secara masal melalui media informasi yang ada. Banyak umat Islam yang mampu memanfaatkan teknologi perkembangan informasi saat ini demi kelangsungan dakwah islam.

\section{Metode Penelitian}

Penelitian ini menggunakan metode Analisis isi (Content analysis). Analisis isi (Content analysis) adalah sebuah teknik yang digunakan untuk digunakan untuk menganalisis dan memahami teks. Analisis ini dapat diartikan sebagai teknik menguraikan secara objektif. Peneliti dapat belajar banyak tentang masyarakat dengan menganalisis koran, majalah, program televisi, music ataupun media lainnya. Penelitian yang menggunakan analisis isi (Content Analysis) tidak mempelajari orang-orang, tetapi 
mempelajari komunikasi yang diciptakan orang tersebut. Dalam analisis ini, penulis hanya terfokus pada cangkupan pesan dakwah kategori ahklaq saja.

\section{Hasil dan Pembahasan}

Media dakwah adalah alat yang dipergunakan untuk menyampaikan materi dakwah. (Rachmad, 1992, p. 35) Secara etimologi berarti alat perantara. Media dakwah yaitu alat yang dipergunakan untuk menyampaikan materi dakwah (ajaran islam) kepada mad'u. dengan banyaknya media yang ada, maka da'I harus memilih media yang paling efektif untuk mencapai tujuan dakwah.(Ilaihi \& Kamsyah, 2010, p. 9) Media dakwah merupakan alat atau sarana yang dipergunakan untuk berdakwah dengan tujuan suaya memudaahkan penyampaikan pesan atau dakwah kepada mad'u.(PutihSaifullah, 2006, p. 100)

Pesan yang dimaksud dalam proses komunikasi adalah sesuatu hal yang disampaikan pengirim kepada penerima. Pesan meupakan seperangkat lambang bermakna yang disampaikan oleh komunikator kepada komunikan (Effendy, 2005)

Sementara Astrid mengatakan bahwa pesan adalah ide, gagasan, informasi, dan opini yang dilontarkan seorang komunikator kepada komunikan yang bertujuan untuk mempengaruhi komunikan kea rah sikap yang di inginkan oleh komunikator.(Susanto Asrid, 1997, p. 7)

Sosial media merupakan dua unsure yang disatukan dalam satu aplikasi yang mendukung sosialisasi sekaligus sebagai media informasi (Aflaha, 2017, p. 254) Pada era globalisasi seperti ini banyak kalangan masyarakat menggunakan media sosial untuk komunikasi, untuk mencari informasi, dan mendapatkan informasi. Media sosial yang popular sering digunakan adalah media sosial seperti whatsapp, instagram,youtube, line, path, twitter dan lain sebagainya.

Media youtube juga dapat dimanfaatkan sebagai media dakwah melalui konten video ceramah, dengan menggunakan media youtube mempermudah dalam penyampaian dan melihatnya.

\section{Analisis pesan dakwah dalam video yang berjudul "Apa yang harus kita lakukan agar anak berbakti"}

Ada beberapa cara untuk orang tua agar anaknya berbakti kepada kita, yaitu:

a. Jangan engkau persulit, mudahkanlah apa yang menyulitkan. Maka anak akan berlatih bagaimana dia berbakti kepada orang tua. Maksudnya disini jika setiap yang dilakukan anak adalah sebuah kesalahan, sebetulnya anak tidak tahu bawha itu salah. Tapi apabila kita mudahkan dia dengan memaafkan keslahan si anak, maka anak tersebut akan berlatih bagaimana dia berbakti kepada orang tuanya.

b. Lihatlah potensi yang ada pada si anak, meskipun itu sebuah potensi kecil, si orang tua tidak perlu ataupun tidak uah membandingkan potensi si anak dengan anak lainnya. Karen setiap anak memiliki potensi dan kelebihan satu sama lainnya. Rasulullah pernah berkata, "jika kamu memperhatikan hal kecil dari aanak, maka anak akan berlatih untuk berbakti kepada kedua orang tuanya”. 
c. Janganlah si orang tua membebani otak dan hidup si anak, seorang anak itu harus betul betul dia rilex, nyaman dan betul betul otak anak tidak dibebani dengan berbagai aspek, baik itu mengejar dari intelejensi ataupun cita-cita . anak itu harus senang, diajarkan perlahan oleh orang tuanyan bagaimana cara memahami hidup.

d. Janganlah orang tua memaki anaknya, memarahi anaknya. Jika anak sering dimarahi ataupun dimaki, secara tidak langsung si anak akan belajar memaki dan marah, sebagaimana orang tuanya memaki dan marah kepadanya.

Itulah beberapa point cara orang tua mengajarkan anaknya agar berbakti kepada kita, bantu anak kita dengan beberapa cara tersebut, arahkan dan berikan yang terbaik dan selalulah berdo'a kepada Allah SWT.

Dalam pesan dakwah yang dismpaikan ustadz Ucu tersebut, dijelaskan beberapa cara orang tua agar ikut serta mengajarkan dan mendidik anaknya supaya berbakti kepada mereka, dan agar si anak tidak tumbuh dan berkembang menjadi anak yang durhaka kepada orang tuanya. Cara tersebut bisa orang tua praktekan sedini mungkin ,agar si anak sudah terlatih dan sudah terbiasa berbakti kepada kedua orang tuanya.

Berbakti kepada kedua orang tua merupakan hal wajib dalam islam, tetapi jika orang tuanya tidak membantu si anak, itu tidak akan efektif, karena si anak tidak mungkin instan berbakti kepada kedua orang tuanya tanpa diajarkan. Proses komunikasi antara orang tua dan anak tercermin dalam al-Qur'an sanga banyak. Masing-masing dari komunikasi tersebut memiliki bentuk, tujuan, nilai, dan materi yang berbeda-beda.

Orang tua dan anak harus memiliki komunikasi yang baik, mengajarkan kepada anak dengan bahasa yang baik agar si anak belajar berbakti kepada orang tuanya. Jika orang tua mengajarkan dengan bahasa yang kasar ataupun tidak baik, contohnya mengajarkan dengan memaki dan marah kepada si anak agar berbakti kepada kedua orang tuanya, sedangkan orang tuanya sendiri mengajarkan dengan cara dan bahasa yang salah dan tidak baik. Hal tersebut tidak akan membuat anak berbakti kepada mereka, malah akan membuat si anak menjadi pribadi yang pemarah dan bisa menjadi durhaka. Karena dengan cara orang tua yang mengajarkan dengan membentak, memarahi dan memaki, justru si anak secara tidak langsung belajar dari orang tuanya bagaimana cara orang tua memarahi, memaki dan membentak si anak.

\section{Analisis pesan dakwah dalam video yang berjudul "Mencari solusi tegaknya pendidikan islam di zaman digital"}

Ustadz Ucu menjelaskan bagaimana mencari solusi untuk menegakan pendidikan islam di era digital. Kemoderenan seseorang akan bertambah semakin rumit, tetapi orang yang tidak meiliki ilmu atau darjah, peningkatan hidupnya tidak akan berubah. Pendidikan sangat dibutuhkan sekali untuk meningkatkan ilmu, tetapi ada beberapa persoalan yang harus dipecahkan yaitu: 
1. Persoalan fisik, disamping kemodernan ini, kita tidak boleh mengikuti kemodernan tanpa arus yang jelas

2. Persoalan masalah batin, banyak terjadinya orang-orang yang stress bahkan samapi depresi, yang anak itu didedikasi moral. Sedangkan mental dan moral yang bagus, in sya Allah SWT akan menghasilkan anak yang baik dan sukses suatu saat nanti.

Ada beberapa factor yang menyebabkan kerusakan otak permanen pada anak, yaitu pornograpi, dimarahi dan memarahi, narkoba serta penyeda rasa/msg. Jika anak sekolah di pesatren atau di sekolah manapun, yang empat hal tersebut harus terkontrol baik oleh orang tua ataupun oleh guru.

Untuk menghindari anak mengalami kerusakan otak permanen, maka orang tua ataupun guru harus bisa mengarahkan anak pada hal positif, caranya yaitu dengan menekankan anak untuk membaca alqur'an, kemudian mengarahkan anak agar bergaul dengan orang-orang baik dan sholeh. Hal tersebut bisa menjadikan pola pendidikan untuk membuat anak menjadi lebih kuat di otak, dan menghindari kerusakan otak permanen pada anak.

Pendidikan itu akan kuat apabila mempola empat hal, yaitu Shidiq, Amanah, Fathonah, dan Tabligh. Tingkat keberhasilan seorang itu bukan dilihat dari keahlian, tetapi dari soft skill dari empat pola tersebut. Main set seseorang dipengaruhi tiga hal, dalam hal pendidikan apapun, yaitu:

1. Skill

2. Gaya belajar

3. Goals/ Tujuan dan visi kita.

Maka solusi yang didapat yaitu, baik orang tua ataupun guru harus mengontol anak dari empat hal yang tadi sudah disebutkan, bisa engan membatasi anak untuk bermain gadget, mengarahkan anak pada hal baik, seperti menajak anak untuk membaca alqur'an ataupun mengajak anak untuk mengaji, memberi arahan agar anak bergul dengan lingkungan serta yang baik dan sholeh, mengajarkan anak dengan bahasa yang baik, tidak dengan memarahi atau membentak anak.

\section{Kesimpulan}

Dalam menyampaikan dakwanya, Ustadz Ucu Najmudin lebih cenderung memberikan pesan dakwah serta menerangkan terkait akhlaq yaitu seputar parenting kepada anak. Penyampaian isi dakwah menggunakan bahasa yang mudah dimengerti oleh mad'unya dengan diselingi guyonan-guyonan agar mad'u tidak bosan dengan pesan atau materi yang disampaikan. Kelebihan media youtube sebagai media dakwah, 
Syarah Siti Maesyaroh, Andri Hendrawan

yaitu demgan mudah mad'u bisa mengakses konten ini, dimanapun mereka berada, serta kapanpun mereka mau, serta bisa menambah banyak wawasan lebih luas.

Sedangkan kekurangan media youtube sebagai media dakwah yaitu, da'I yang menyampaikan materi serta pesan harus dengan jelas, agar mad'u yang mendengar dan menonton konten tersebut tidak salah mengartikan sehingga menimbulkan salah persepsi. Karena media youtube sebagai media dakwah itu, termasuk pada komunikasi satu arah, sehingga tidak terjadinya feedback antara da'I dan mad'u. 


\section{BIBLIOGRAFI}

Aflaha, U. (2017). Kaos Hadis Sebagai Media Dakwah dan Komunikasi Alternatif. INJECT (Interdisciplinary Journal of Communication), 2(2), 247-274.

Effendy, O. U. (2005). Ilmu Komunikasi Suatu Teori dan Praktik. Bandung: Remaja Rosdakarya.

Ilaihi, W., \& Kamsyah, A. (2010). Komunikasi dakwah. Remaja Rosdakarya.

Indrawati, I. (2013). MENGAPRESIASI NOVEL SEBAGAI MEDIA DAKWAH BILQALAM. Wardah, 14(2), 217-226.

Kustandi Suhendang. (2007). Manajemen Pers Dakwah. Bandung: Marja.

Putih-Saifullah, J. (2006). Dakwah Tekstual Dan Kontesktual. Yogyakarta: AK Group.

Rachmad, D. (1992). Sistem Etika Islam (Akhlak Mulia). Jakarta: Pustaka Panji Mas.

Susanto Asrid. (1997). Komunikasi Dalam Teori Dan Praktek. Bandung: Bina Cipta e-repository.perpus.iainsalatiga.ac.id. 